\title{
LOW PRESSURE INJECTION OF OXYHYDROGEN IN TURBOCHARGED COMPRESSION IGNITION ENGINES
}

\author{
Levente Barna, Dorin Lelea
}

Original scientific paper

The paper proposes to analyse experimentally the influence of using oxyhydrogen gas, resulting from a process of electrolysis produced on board the vehicle, in supercharged compression ignition engine. The experiment consists in the series of the constant load tests (the same position of the accelerator), on the chassis dynamometer, initially starting with conventional fuel (standard diesel oil) and in the second phase by introducing the oxyhydrogen through engine manifold of the vehicle, with different volume percentages. The experimental data reveal a positive influence of the added oxyhydrogen on opacity of the flue gas and an increase of the $\mathrm{NO}_{\mathrm{x}}$ concentration. The mechanical parameters of the engine just highlighted certain trends, resulting in definitely the favourable enriching influence of oxyhydrogen.

Keywords: compression ignition engines; diesel; flue gas opacity; HHO; hydrogen; internal combustion engine; NO; oxyhydrogen

Niskotlačno ubrizgavanje elektrolitičkog plina u motore s turbokompresijskim paljenjem

Izvorni znanstveni članak

U radu se predlaže eksperimentalna analiza utjecaja primjene elektrolitičkog plina (oxyhydrogen gas) kao rezultata postupka elektrolize provedene na vozilu, u motoru $s$ kompresijskim paljenjem. Eksperiment se sastoji od niza testova trajnog opterećenja (isti položaj akceleratora), na šasiji dinamometra, započinjući s uobičajenim gorivom (standardno gorivo za diesel motore), a u sljedećoj fazi uvodeći elektrolitički plin (plin kisika i vodika) kroz razdjelnik motora vozila, uz različite postotke volumena. Eksperimentalni podaci pokazuju pozitivan utjecaj dodanog elektrolitičkog plina na neprozirnost dimnog plina i porast $\mathrm{NO}_{\mathrm{x}}$ koncentracije. Mehanički parametri motora istaknuli su određene trendove, rezultirajući s definitivno korisnim obogaćujućim utjecajem elektrolitičkog plina.

Ključne riječi: diesel; elektrolitički plin; HHO; motori s kompresijskim paljenjem; neprozirnost dimnog plina; NO $O_{x}$; vodik; motor s unutrašnjim izgaranjem

\section{Introduction}

Our world is the energy consumption one, since almost all human actions, excluding its energy activities developed through the human body metabolism, are accompanied by the energy produced from the combustion of the fossil fuels. Such global daily energy consumption reaches unimaginable values, so considering that today ever known fossil fuel reserves are relatively limited, the mankind is looking for the implementation of the new solutions. Reducing the fuel consumption of equipments, such as furnace, burners and internal combustion engines, might be obtained by raising the combustion efficiency or possibly managing the fuel composition that decreases consumption.

Internal combustion engines are the significant part of equipment that consumes fossil fuels. This topic is generally the one with continuous research, focused on increasing the thermal cycle efficiency of Diesel or Otto engines. Some of the examples are obtained by the energy recovery solutions, hybrid electric and flexible engines with multi-fuel solution or fuel enrichment primarily with methane, propane or hydrogen.

Dieguezetal [1] presented a research on commercial 1.4 L four-cylinder Volkswagen spark-ignition engine previously adapted to operate on pure hydrogen that has been fueled with hydrogen/methane mixtures with $5 \div 20$ vol.\% methane $(29.6 \div 66.7$ wt.\%). A clear positive effect of reducing the spark advance on the specific $\mathrm{NO}_{\mathrm{x}}$ emissions has been observed. In the case of $\mathrm{CO}$ and unburned hydrocarbons (HCs), their specific emissions increase with the methane content of the fuel mixture. However, they also increase as $k$ increases in spite of the lower fuel concentration due to a proportionally higher reduction of the power. The higher engine speed effects positively the $\mathrm{CO}$ and $\mathrm{HCs}$ emissions but has the negative effect on NOx emissions due to the improved mixing and higher temperatures associated with higher turbulence in the cylinders.

Kose and Ciniviz [2] performed the experimental research on compression ignition engine (CI) with 17/1 compression ratio, four cylinders, four stroke, turbocharger and 3.908 litters engine. A diesel fuel was injected directly to combustion chamber while the hydrogen was added to inlet manifold. The obtained results reveal an increase in engine torque, power, thermal efficiency, nitrogen oxides (NOx) and temperature of the exhaust gasses. Besides, a decrease in hydrocarbons (HC), carbon monoxide $(\mathrm{CO})$ and oxygen $\left(\mathrm{O}_{2}\right)$ is observed.

$\mathrm{Xu}$ et al. [3] presented an experimental research on compression ignition engines working with hydrogendiesel oil blending. They reported a dependency between the timing of injection and quantity of injected hydrogen. The optimal timing of injection increases with hydrogen flow rate.

Dulger and Ozcelik [4] made a research about the "on board" production systems of the oxyhydrogen on various vehicles. They found substantial reductions in fuel consumption $(26 \div 43 \%)$, noting that using this type of gas in internal combustion engines has a beneficial impact on flue gas emissions.

Zhangetal [5] investigated the possibilities on using the hydrogen as a supplementary fuel in diesel engines. It was found that enrichment diesel oil with hydrogen can reduce fuel consumption on the entire range of the engine operation, but does not reduce overall fuel consumption (diesel with hydrogen). Moreover under high loads conditions the total fuel consumption increases. Another 
conclusion would be that increasing temperature of the added hydrogen can reduce the total fuel consumption even under heavy load.

Song [6] concluded that, if conventional diesel engine operates with high mass concentrations of blended hydrogen, initially it ignites the diesel-air mixture and the produced heat will be the source for ignition of the hydrogen-air mixture, generating as wirl flow inside the cylinder during combustion.

Yilmaz et al. [7] performed an experimental study in order to investigate the impact of the oxyhydrogen (HHO), introduced to the intake manifold of a directinjection CI engine under various loads, on the engine performance. It was found that $\mathrm{HHO}$ addition to the engine without any modification, resulted in increasing engine torque output by an average of $19.1 \%$, reducing $\mathrm{CO}$ emissions by an average of $13.5 \%$, HC emissions by an average of $5 \%$ and SFC by an average of $14 \%$.

Saravanan and Nagarajan [8] investigated experimentally the influence of oxyhydrogen injection methods in cylinder for compression ignition engines. It was shown that there are notable differences, both in the case of mechanical parameters of the engine, and emission parameters. Depending on the oxyhydrogen injection method used, different values for optimum injection timing are obtained, for the same amount and injection time of oxyhydrogen.
Maki and Prabhakaran [9] investigated experimentally a continuous induction of hydrogen in the air inlet manifold of a multi cylinder, compression ignition engine in order to evaluate engine performance and exhaust gas emissions, under different hydrogen induction rates and loads. The investigation reveals that the optimum rate of hydrogen induction is $7.5 \mathrm{l} / \mathrm{min}$. This optimum rate reduced the diesel fuel consumption by 20 $\%$ and increased the brake thermal efficiency by about $8 \div 9 \%$. Moreover, the $\mathrm{NO}_{\mathrm{X}}$ emission is reduced.

Abhilashetal [10] made an experimental research in order to evaluate performance of internal combustion engine fed by the oxyhydrigen as an addition to the basic fuel. The results indicated increase of $4 \%$ in brake thermal efficiency with the use of sodium hydroxide electrolyte. It is observed that the fuel consumption of the engine is reduced notably with increase in electrolyte concentration. The explanation lays in the fact that flame propagation rate and the excess oxygen presented in oxyhydrogen supplement, increases the efficiency of the engine.

King [11] presented the review on using the hydrogen obtained by electrolyzes. Most investigators believe the energy results from burning hydrogen. The hypothesis, proposed in this work, explains that the dominant energy is not coming from hydrogen, but rather from charged water gas clusters, which activate and coherently trap zero-point energy.

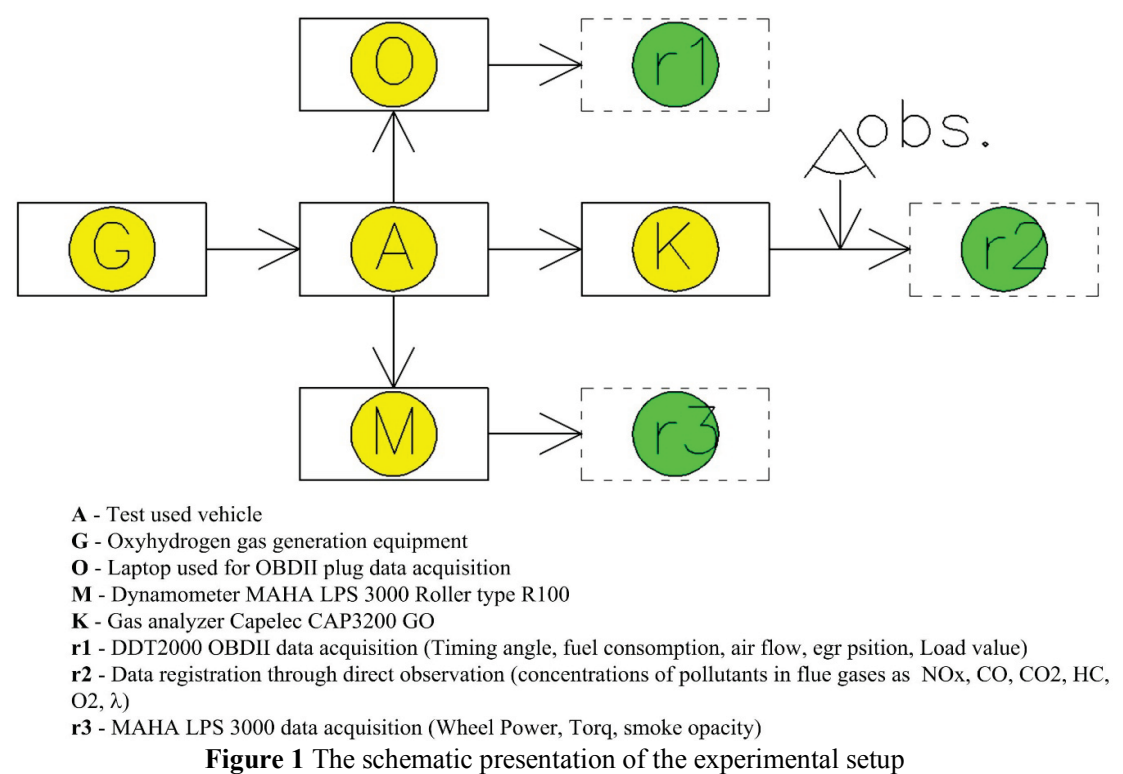

Kosaretal [12] presented the research on small gasoline engine running with slightly rich mixture, without catalytic converter. It was found that when the gasoline engines are operated with pure hydrogen, $\mathrm{NO}_{\mathrm{x}}$ emissions increase and the backfire occurs. Also the specific fuel consumption and $\mathrm{NO}_{\mathrm{x}}$ emissions were reduced by about $57 \%$ and $66 \%$, respectively at hydrogen operation. Moreover, the near zero values for $\mathrm{CO}, \mathrm{CO}_{2}$ and $\mathrm{HC}$ emissions were obtained. The test results showed that the small gasoline engine can operate with pure hydrogen at a suitable mixture without any backfire, and provide important improvements in emissions and fuel consumption without using any exhaust control system, electronic ignition system and fuel injection system.
Considering the large dispersion of results obtained by researchers, the experimental research is made on the engine that is mounted on a commercial vehicle. In this case the injection pressure of the oxyhydrogen is lowered from $1800 \mathrm{~Pa}$ to $300 \mathrm{~Pa}$, on the "on board" oxyhydrogen production system. The vehicle was tested on a chassis dynamo meter to measure the mechanical parameters and the concentration of pollutant emissions.

\section{The experimental setup}

The experimental setup consists of commercial vehicle equipped with $1.5 \mathrm{dci}$ diesel engine, Dynamometer MAHALPS3000RollertypeR100, gas 
analyzer CapelecCAP3200GO and Equipment for $\mathrm{HHO}$ generation (Fig. 1).

Gas analyzer CapelecCAP3200GO was used to determine the concentration of pollutants in flue gases such as $\mathrm{NO}_{\mathrm{x}}, \mathrm{CO}, \mathrm{CO}_{2}, \mathrm{HC}$.

Oxyhydrogen gas generation equipment is a dry electrolyzer with multiple plates served by a series of auxiliary elements. It is designed as an electro-mechanical assembly to produce water electrolysis. The main elements of this installation are presented in Fig. 3.

From the previous experiments it is found that three main electrodes (anode and cathode) are sufficient for the electrolysis cell. There are also eight neutral electrodes that alternate the main electrodes at a distance of $3 \mathrm{~mm}$ between consecutive electrodes. The concentration of the solution was up to $17.5 \%(207,5 \mathrm{~g} \mathrm{NaOH} /$ liter $)$. The concentration of the solution was reduced compared with the previous experiments to ensure maximum conductance and to avoid deposition of crystals of $\mathrm{NaOH}$ on various surfaces of the reactor. The maximum volume flow rate of the reactor was approximately1 $1 / \mathrm{min}$.

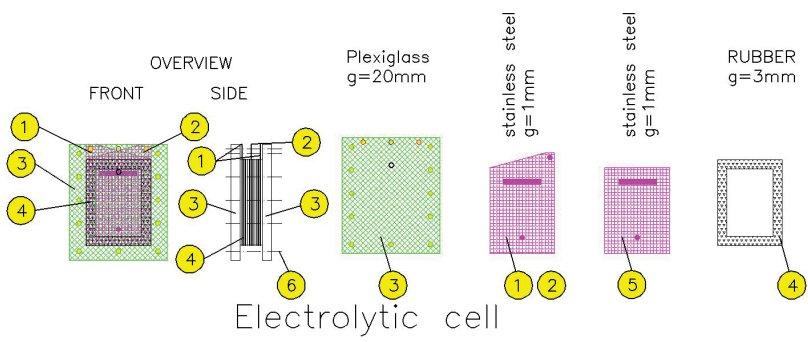

Figure 2 The components of the oxyhydrogen generator

The generator itself is designed as an electrolysis vessel with anode and cathode plates with neutral plates fixed between them. Following the analysis of existing devices, a dry cell electrolysis with small electrolyte volume, multiple electrodes (11 electrodes), average applied voltage $(10 \div 14 \mathrm{~V})$, with the sodium hydroxide electrolyte solution of high concentration $(17.4 \%)$ was selected.

\section{Experimental procedure}

The oxyhydrogen generator system, presented in Fig. 3 was mounted on the test vehicle with minimal modifications made on car engine, primarily by fitting the oxyhydrogen injector on air intake route of the car engine. The experiment is conducted in two stages:

Table 1 The Load parameters used in the experiments

\begin{tabular}{|c|c|c|c|}
\hline Load & $\begin{array}{c}\text { Pedal position } \\
(\%)\end{array}$ & $\begin{array}{c}\text { EGR valve position } \\
(\%)\end{array}$ & $\begin{array}{c}\text { Engine speed } \\
(\mathrm{rpm})\end{array}$ \\
\hline Load 1 & 7.083 & $40 \pm 2$ & $1650 \div 1690$ \\
\hline Load 2 & 15.588 & $34 \pm 2$ & $2520 \div 2566$ \\
\hline Load 3 & 20.474 & $28 \pm 2$ & $2930 \div 2970$ \\
\hline
\end{tabular}

In the first stage the measurements on the composition of the exhaust gases $\left(\mathrm{NO}_{\mathrm{x}}, \mathrm{CO}_{2}, \mathrm{CO}, \mathrm{HC}, \mathrm{O}_{2}\right.$, $\lambda$ ) and engine parameters (wheel power, instantaneous fuel consumption, timing angle of main injection, etc.) are performed, with diesel oil respectively diesel oil blended with oxyhydrogen considering the parameters presented in Tabs. 1 and 2.
In the second phase of the measurements, the exhaust gas opacity is measured. It has to be emphasized that the test vehicle is equipped with a turbodiesel engine without intercooler, with EURO3 standards.

Table 2 The measurements sequences of blended HHO in diesel

\begin{tabular}{|c|c|c|c|}
\hline 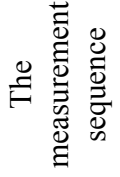 & $\begin{array}{l}\text { Oxyhydrogen } \\
\text { gas supply } \\
\text { pressure } \\
\left(\mathrm{mm} \mathrm{H}_{2} \mathrm{O}\right)\end{array}$ & $\begin{array}{l}\text { Oxyhydrogen } \\
\text { gas volumetric } \\
\text { flow } \\
(\mathrm{lpm})\end{array}$ & $\begin{array}{c}\text { Electrolysis } \\
\text { current } \\
\text { (A) }\end{array}$ \\
\hline $\mathrm{D}$ & 0 & 0 & 0 \\
\hline $\mathrm{p} 1$ & 3.5 & 0.1 & 2.4 \\
\hline $\mathrm{p} 2$ & 5 & 0.3 & 5.93 \\
\hline p3 & 7 & 0.45 & 9.4 \\
\hline $\mathrm{p} 4$ & 8 & 0.7 & 12.66 \\
\hline
\end{tabular}

The measurement procedure has been organized in two steps. During the first step the Load 1 conditions, presented in Tab. 2, were fixed. After attaining the steady - state regime the following data are recorded: on the MAHALPS3000R100 (wheel power, speed, time), the parameters monitored by the OBDII plug vehicle (fuel instant consumption, intake airflow, intake manifold air pressure, intake manifold air temperature, fuel temperature, engine coolant temperature, ambient pressure) respectively the flue gas composition on CAPELEC gas analyser CAPGO3200 $\left(\mathrm{NO}_{\mathrm{x}}, \mathrm{CO}_{2}, \mathrm{CO}\right.$, $\left.\mathrm{HC}, \mathrm{O}_{2}, \lambda\right)$. The concentrations of pollutants are taken as an average over the $120 \mathrm{~s}$ for each blended oxyhydrogen sequence, (Tab. 4). For the prescribed Load conditions, the several sequences of blended oxyhydrogen namely $\mathrm{D}$, $\mathrm{p} 1, \mathrm{p} 2, \mathrm{p} 3, \mathrm{p} 4$, are maintained for $120 \mathrm{~s}$.

During the second step, with the gearbox in the neutral position, successive accelerations are performed, from idling speed until reaching the motor vehicle speed limit. For each sequence of blended oxyhydrogen, the engine was accelerated three times, maintained approximately 2 seconds at the maximum speed. It is considered that the maximum flue gas opacity is obtained at the last moment of acceleration. The average of the peak values is considered, from each series of accelerations with the same rate of the blended oxyhydrogen.

\section{Results and discussions}

The measurements on using the blended oxyhydrogen in diesel oil are performed on the commercial diesel engine $1.5 \mathrm{dci}$. The low intake air pressure is considered as well as the low flow rate of the blended oxyhydrogen (up to $11 / \mathrm{min}$ ).

In Fig. 4 the concentration of the oxygen in the flue gases versus the oxyhydrogen flow rate is presented.

Decreased oxygen concentration or increasing concentration of carbon dioxide in the flue gas indicates that something extra burns. It is known that there are no other compounds that could burn, rather than particles, whose concentration decreases (decreasing opacity of the flue gas) Moreover, the concentration of unburnt hydrocarbons and carbon monoxide is very small. Consequently, one can conclude that there is a more complete combustion, due to burning of diesel particulates from flue gases. 
Table 3 The main parameters of the tested engine

\begin{tabular}{|c|c|c|c|c|c|c|}
\hline $\begin{array}{l}\text { Volume } \\
\left(\mathrm{cm}^{3}\right)\end{array}$ & Nr. Cylinders & Nr. Valves & $\begin{array}{c}\text { Pollution } \\
\text { Level }\end{array}$ & $\begin{array}{c}\text { Max. power } \\
(\mathrm{kW})\end{array}$ & $\begin{array}{l}\text { Max. Torque } \\
(\mathrm{N} \cdot \mathrm{m})\end{array}$ & $\begin{array}{c}\text { Max. Torque Speed } \\
(\mathrm{rpm})\end{array}$ \\
\hline 1461 & 4 & 8 & Euro 3 & 48 & 160 & 2000 \\
\hline $\begin{array}{l}\text { Injection } \\
\text { type }\end{array}$ & Fuel & $\begin{array}{l}\text { Consumption } \\
\text { (complete } \\
\text { cycle) }\end{array}$ & $\begin{array}{l}\text { Consumption } \\
\text { (urban cycle) } \\
(1 / 100 \mathrm{~km})\end{array}$ & $\begin{array}{c}\text { Consumption } \\
\text { (extra-urban cycle) } \\
(1 / 100 \mathrm{~km})\end{array}$ & $\begin{array}{c}\mathrm{CO}_{2} \text { emissions } \\
(\mathrm{g} / \mathrm{km})\end{array}$ & Vol. ratio \\
\hline Common rail & Diesel & 4.8 & 5.8 & 4.3 & 128 & $18.3: 1$ \\
\hline
\end{tabular}

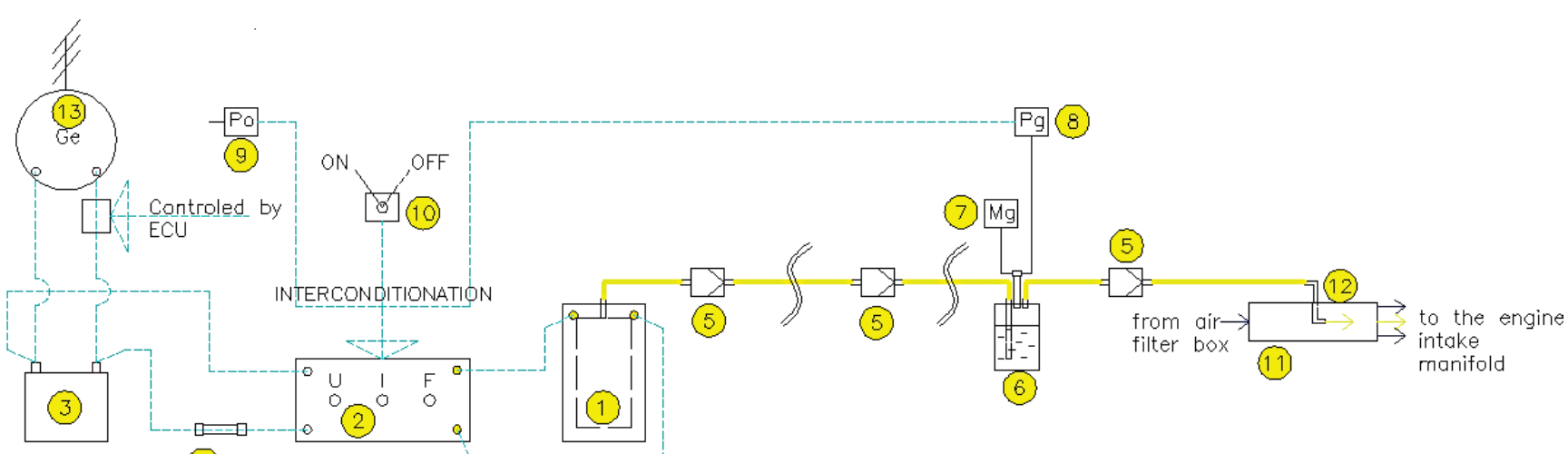

(4)

1 - Oxyhydrogen gas generator as an electrolysis vessel with anode and cathode plates interposed neutral;

2 - PWM - pulse-witdh modulator with valtage control $(U)$, current $(I)$ and frequency $(F)$;

3 - Voltage source (battery) $12 \mathrm{~V} D c$ - enter the standard construction of the vehicle used in the test

4 - 32A Fuse

5 - Drops filters for separating the liquid phase of water in the form of moisture remaining in the gas generated;

6 - Safety water volume for preventing flame propagation in case of accident
7 - Measuring socket for digital pressure gouge; 8 - Pressure switch to limit the operating pressure of the HHO generator;

9 - Oil pressure switch located in the main lubricating rail of engine for interconditioning operation of tha gas generator:

10 - General electric switch for system deactivation;

11 - Main air intake duct of the engine, located 11 - Main air

after air filter;
12 - Oxyhydrogen gas injection point in the main engine inlet duct;

13 - Generator - standard in the construction of the vehicle used to test.

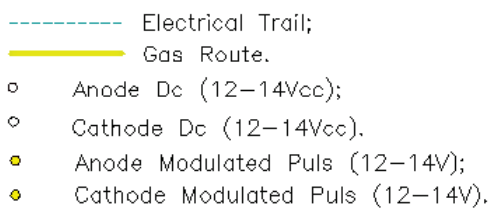

Figure 3 The general scheme of the oxyhydrogen generator installation

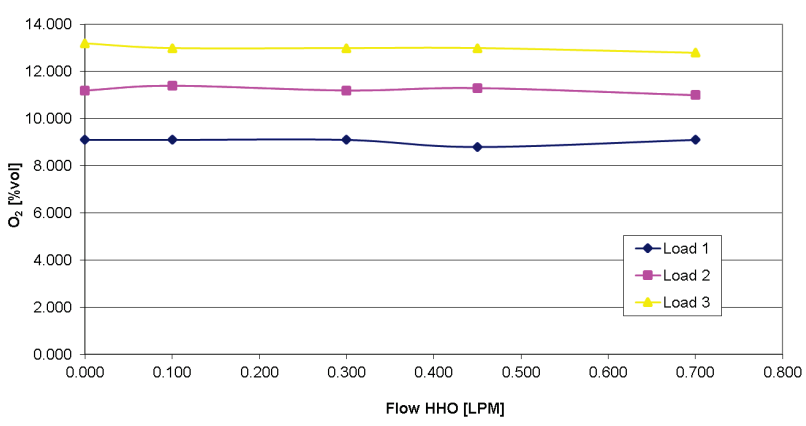

Figure 4 The $\mathrm{O}_{2}$ concentration variation versus injected $\mathrm{HHO}$ for three different loads

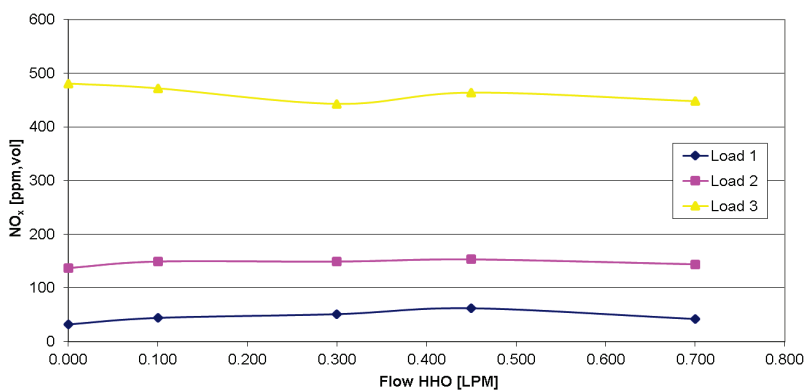

Figure 5 The $\mathrm{NO}_{\mathrm{x}}$ concentration variation versus injected $\mathrm{HHO}$ for three different loads
In Fig. 5 the concentration of $\mathrm{NO}_{\mathrm{x}}$ in the flue gases versus the oxyhydrogen flow rate is presented. The concentration of $\mathrm{NO}_{\mathrm{x}}$, at the same percentage of flue gas recirculation, increases with increasing the engine load. The higher concentrations are the outcome of the higher combustion temperatures.

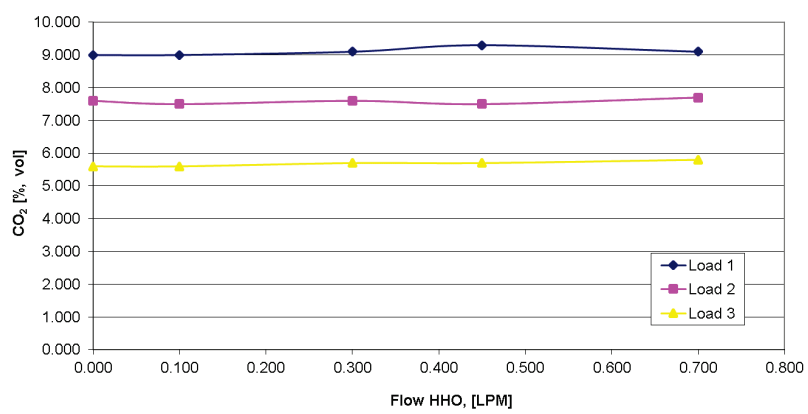

Figure 6 The $\mathrm{CO}_{2}$ concentration variation versus injected $\mathrm{HHO}$ for three different loads

In Fig. 6 the concentration of $\mathrm{CO}_{2}$ in the flue gases versus oxyhydrogen flow rate is presented. Generally low level of unburned hydrocarbons and carbon monoxide 
shows that there is a low level of pollutants, both when operating with diesel and the addition of $\mathrm{HHO}$.

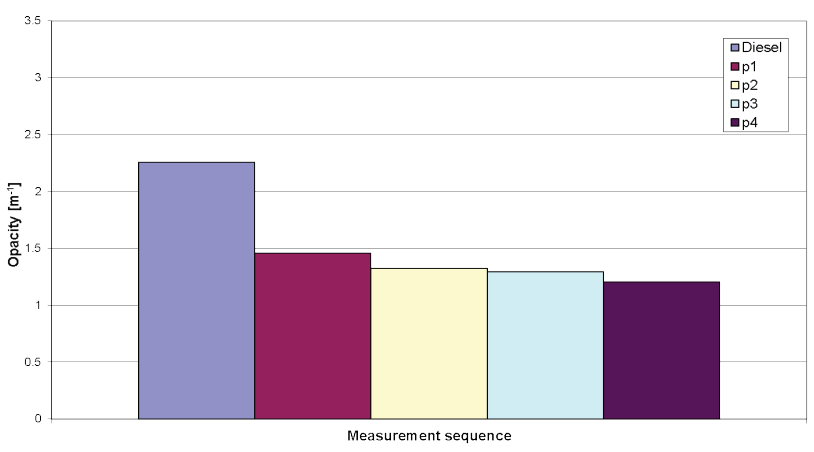

Figure 7 The smoke opacity variation for various sequences of injected $\mathrm{HHO}$
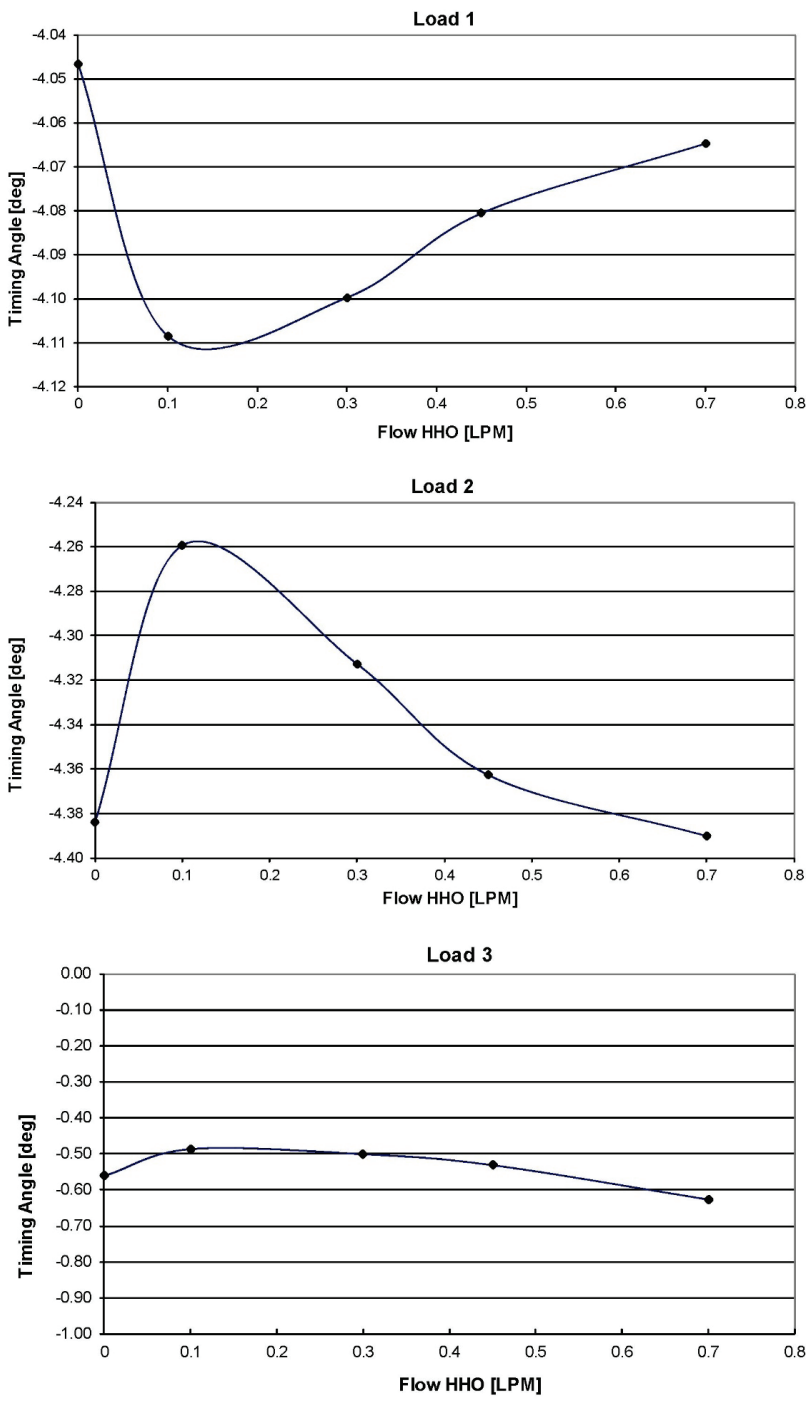

Figure 8 The timing angle variation versus HHO flow rate for three different loads

In Fig. 7 the opacity for several blended sequences of oxyhydrogen rate is presented. Given that the tested engine is EURO3, the concentration of $\mathrm{CO}$ at idling speed of $2 \div 3000 \mathrm{rpm}$ for EURO 3 and EURO 4, pollution standard values are $0.3 \%$ respectively $0.2 \%$. It might be seen that the absolute value of the flue gas opacity when operating with both diesel fuel and addition of $\mathrm{HHO}$, attaining the values of $2.25 \div 2.3 \mathrm{~m}^{-1}$ respectively
$1.25 \div 1.45 \mathrm{~m}^{-1}$, versus $3 \mathrm{~m}^{-1}$ limit imposed for EURO3 standards. Moreover it is below the value of $1.5 \mathrm{~m}^{-1}$, the limit imposed for vehicles with EURO4 standards. In Fig. 8 the timing of main injection is presented for three different loads and various blended sequences of HHO.

For Load 1 timing of main injection shows a minimum value for $\mathrm{p} 1$, then with the increasing amount of $\mathrm{HHO}$ timing of main injection also increases, but that value is preserved below the angle practiced for diesel oil.

This can be explained by the increasing of the fuel burning speed, as the vehicle computer is forced to decrease the injection advance angles and combustion is displaced to expansion stroke. This phenomenon usually favours a better engine torque. In the case of Load 2 timing of main injection attains a maximum value for $\mathrm{p} 1$, then with increasing amount of blended HHO, timing of main injection decreases below the value obtained for engine powered by diesel oil. This might be explained by the higher fuel burn rate. For Load 3 the variation of the timing of the main injection is almost flat, although the similar trend is observed for Load 2.
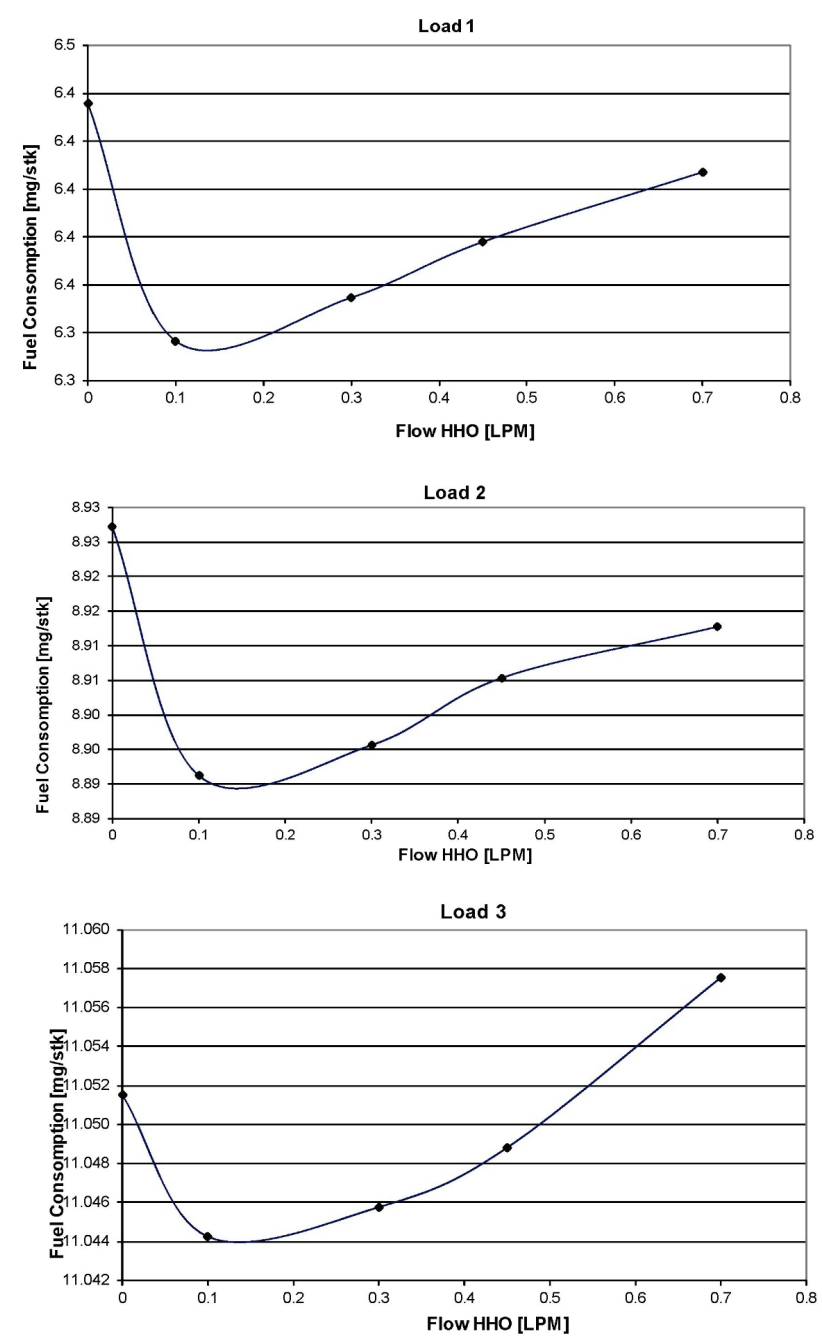

Figure 9 The fuel consumption variation versus HHO flow rate for three different loads

In Fig. 9 the fuel consumption per stroke is presented for three different loads and various blended sequences of HHO. For Load 1, one can notice a minimum value for $\mathrm{p} 1$, then the fuel consumption increases but not over the value obtained for diesel oil, and generally follows the 
variation of the timing of main injection. This means that we have minimal fuel consumption per stroke for the lowest ignition advance angles. For Load 2 one can observe a minimum value of the fuel consumption obtained for $\mathrm{p} 1$ that increases after that point, but not over the case when pure diesel oil is used as the fuel. For Load 3 a minimum value is obtained for $p 1$, after that increases over the value obtained for diesel oil.
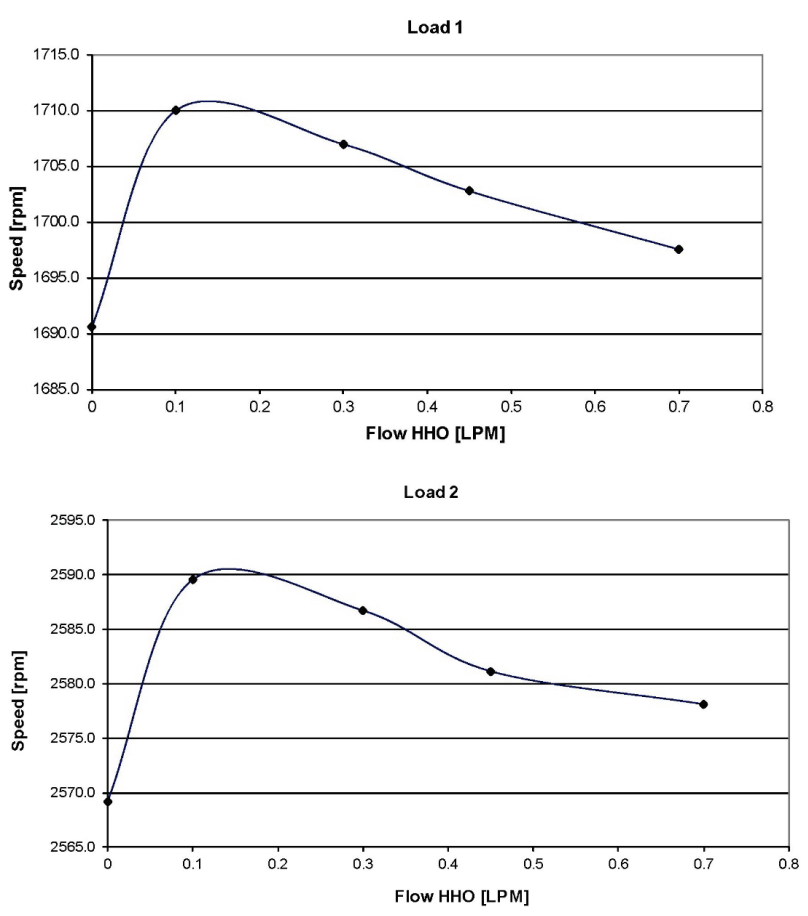

Load 3

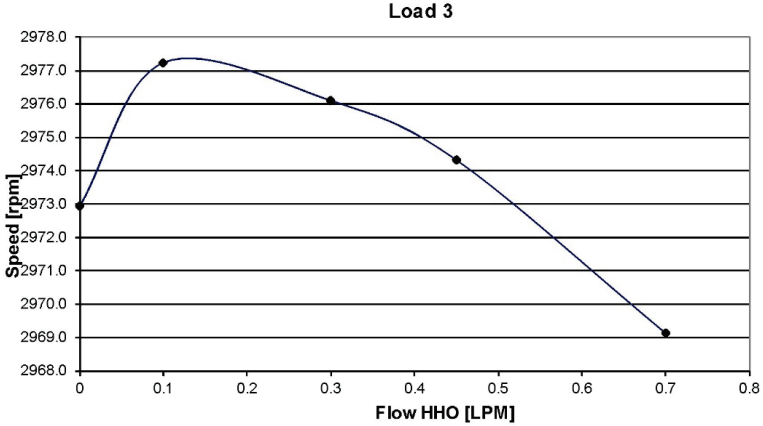

Figure 10 The engine speed variation versus HHO flow rate for three different loads

In Fig. 10 the engine speed is presented for three different loads and various blended sequences of HHO. For Load 1 the maximum speed is observed for $\mathrm{p} 1$, after that it decreases, but not below the value obtained for diesel oil. In the case of Load 2 a maximum speed is once again obtained for $\mathrm{p} 1$, followed by decreasing trend but not below the value obtained for the case when the engine is powered by diesel oil. For Load 3 once again the maximum is obtained for $\mathrm{p} 1$, after that speed decreases below the case of the engine running with diesel oil. It might be explained that the engine speed is influenced by the ignition advance angle. It means that the engine speed increases so the ignition advance angle has to be higher and consequently burning phenomenon is not displaced to the expansion phase. On the other hand for higher flow rates of $\mathrm{HHO}$, fuel consumption increases and the engine speed decreases. Consequently one might conclude that the higher burning speed negatively influenced the engine power and torque.

In Fig. 11 the wheel power for various blended sequences of $\mathrm{HHO}$ and three different loads is presented. It is similar to engine speed variation. For HHO flow rates Between $0.3 \div 0.5 \mathrm{l} / \mathrm{min}$, a disproportion is observed that might assign unfavourable main injection timing that affects the engine torque. However, the amount of power does not drop below the value obtained for diesel oil.

In Fig. 12 the boost pressure in the intake manifold for various blended sequences of $\mathrm{HHO}$ and three different loads is presented. For Load 1, a peak value is obtained for $\mathrm{p} 1$ that confirms the movement of combustion phenomenon to expansion phase. Moreover, as the HHO flow rate increases, it drops below the value obtained when operating with diesel oil.

This might be explained by the unfavourable influence of the main injection timing. For Load 2, the boost pressure shows an increase up to $\mathrm{p} 1$ and asymptotically tends to the maximum that confirms the movement of combustion to the expansion phase.
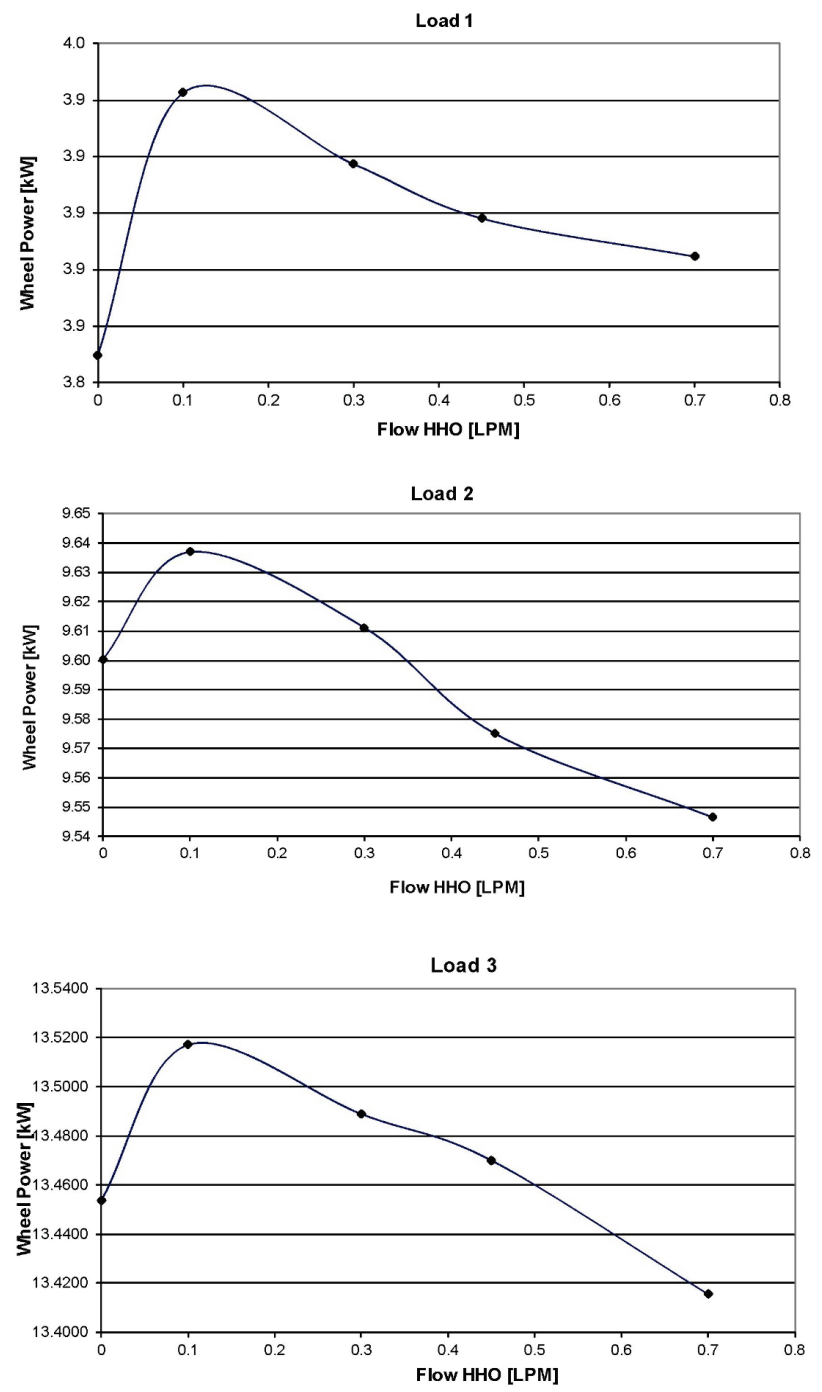

Figure 11 Wheel Power variation versus HHO flow rate for three different loads

In the case of Load 3, the boost pressure attains maximum value throughout the $\mathrm{p} 1$ and then decreases, which could confirm that high rate burning obtained by 
blended HHO occurs much earlier, specifying the fact that main injection timing is advanced and an angle is much higher than in the previous cases. Consequently, less energy is transferred to the compressor that is unable to produce increased pressure.
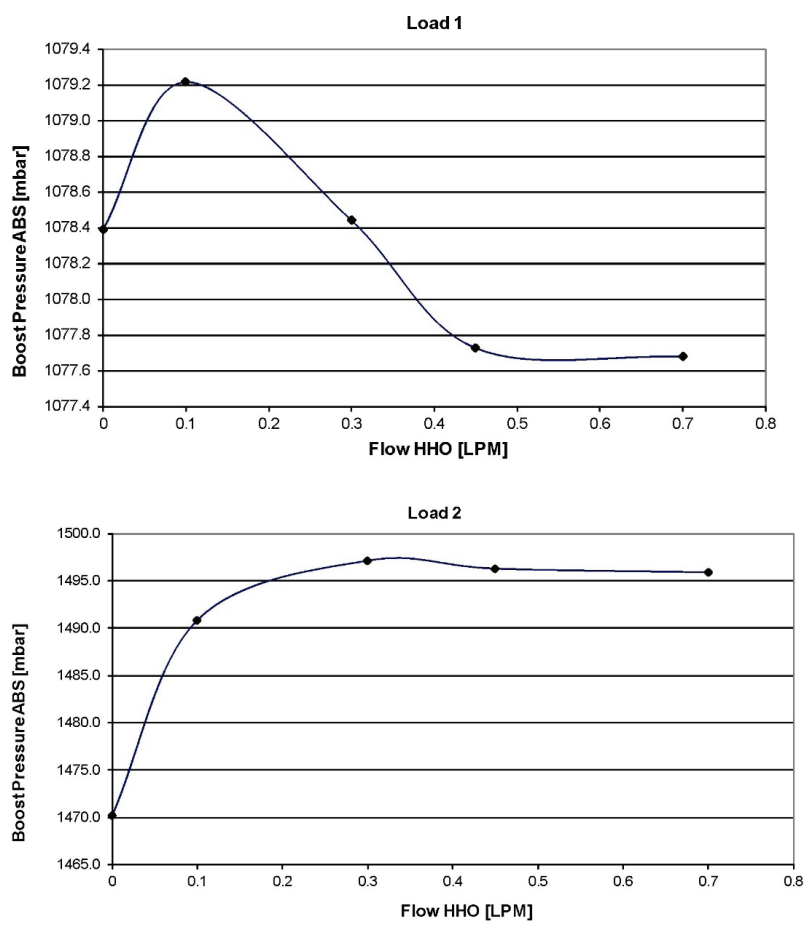

Load 3

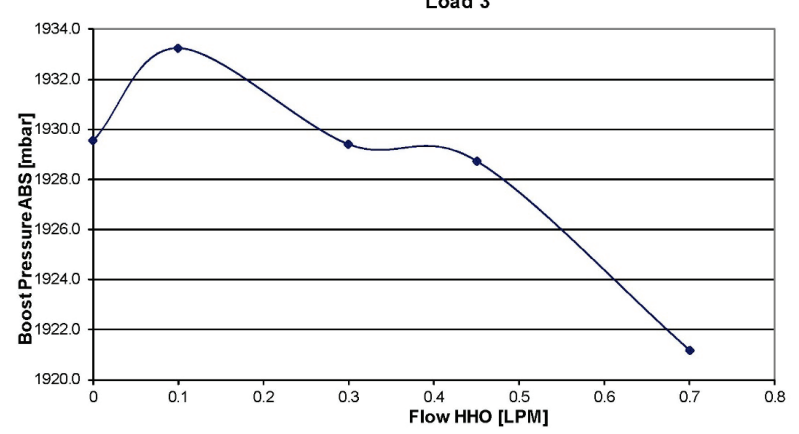

Figure 12 Wheel Power variation versus HHO flow rate for three different loads

\section{Conclusion}

Introducing the oxyhydrogen into the intake manifold of a turbocharged diesel engine at low flow rates (up to1 $1 / \mathrm{min}$ ) and low pressures (up to proximately $300 \mathrm{~Pa}$ ), has the following impact:

- Reduces diesel particles from the flue gases by up to $40 \div 50 \%$;

- Favours a more complete combustion for the range of speeds and loads considered in this research, due to increased burning rate;

- Increasing the combustion temperatures increases the $\mathrm{NO}_{\mathrm{x}}$ level;

- Lowers the fuel consumption per stroke, up to an optimum value of the flow rate of $\mathrm{HHO}$;

- Favours a higher air supply pressure in the intake manifold of the engine for the prescribed load, that might increase the engine power through the optimization of the injection maps;
- $\quad$ Stabilizing the engine speed.

Also considering a long time use engine with $\mathrm{HHO}$ enriched fuel can highlight a favourable effect on the general behaviour of the engine:

- More stable engine operation in time;

- General effect of reducing consumption over time;

- Reduce the amount of CO and HC in the flue gas, favouring low combustion pollutants.

\section{Acknowledgement}

This work was partially supported by the strategic grant POSDRU/159/1.5/S/137070 (2014) of the Ministry of National Education, Romania, co-financed by the European Social Fund - Investing in People, within the Sectorial Operational Programme Human Resources Development $2007 \div 2013$.

\section{References}

[1] Dieguez, P. M.; Urroz, J. C.; Marcelino-Sadaba, S.; PerezEzcurdia, A.; Benito-Amurrio, M.; Sainz, D.; Gandia, L. M. Experimental study of the performance and emission characteristics of an adapted commercial four-cylinder spark ignition engine running on hydrogen-methane mixtures. // App. Energy, 113, (2014), pp. 1068-1076. https://doi.org/10.1016/j.apenergy.2013.08.063

[2] Köse, H.; Ciniviz, M. An experimental investigation of effect on diesel engine performance and exhaust emissions of addition at dual fuel mode of hydrogen. // Fuel Process Technol., 114, (2013), pp. 26-34. https://doi.org/10.1016/j.fuproc.2013.03.023

[3] Xu, T.; Shi, L. M.; Liu, M. S.; Jiang, Z. F.; Liu, Q. Q.; Wang, Z. Z. The establishment of an optimized performance model of in cylinder hydrogen-mixed combustion of the S195 diesel engine. // Transactions of CSAE, 9, 3(1993), 71e7.

[4] Dulger, Z.; Ozcelik, Z. R. Fuel economy improvement by on board electrolytic hydrogen production. // Int. J. Hydrogen Energy, 25, (2000), pp. 895-897. https://doi.org/10.1016/S0360-3199(99)00108-1

[5] Zhang, B.; Fu, W. B.; Wu, X. H. Effect of hydrogen on fuel consumption of diesel engine. // Journal of Combustion Science and Technology, 12, 3(2006), 238e42.

[6] Song, Y. C. Study on fuel-air mixture forming and combustion process in hydrogen-diesel engine of premixed charge compression ignition. // $\mathrm{PhD}$ Thesis, Beijing Jiaotong University, Beijing, China, 2008.

[7] Yilmaz, A. C.; Uludamar, E.; Aydin, K. Effect of hydroxy (HHO) gas addition on performance and exhaust emissions in compression ignition engines. // Int. J. Hydrogen Energy 35, 20(2010), pp. 11366-11372. https://doi.org/10.1016/j.ijhydene.2010.07.040

[8] Saravanan, N.; Nagarajan, G. An experimental investigation on hydrogen fuel injection intake port and manifold with different EGR rates. // Int. J. Energy Environ., 1, 2(2010), pp. 221-248.

[9] Maki, D. F.; Prabhakaran, P. An Experimental Investigation on Performance and Emissions of a Multi Cylinder Diesel Engine Fueled with Hydrogen - Diesel Blends. // World Renewable Energy Congress, Sweden, 2011. https://doi.org/10.3384/ecp110573557

[10] Abhilash, R.; Gopalakrishna, K.; Venkatesh, K. Performance evaluation of an IC Engine using Oxyhydrogen as a fuel supplement. // J. Sci. Ind. Res., 74, (2015), pp. 176-179. 
[11] King, M. B. Water Electrolyzers and the Zero-Point Energy. // Physics Procedia, 20, (2011) pp. 435-445. https://doi.org/10.1016/j.phpro.2011.08.038

[12] Kosar, M.; Ozdalyan, B.; Celik, M. B. The usage of hydrogen for improving emissions and fuel consumption in a small gasoline engine. // J. Therm. Sci. Technol., 31, 2(2011), pp. 101-108.

\section{Authors' addresses}

Levente Barna, PhD Student

University Politehnica Timisoara,

Faculty of Mechanical Engineering

B-dul Mihai Viteazu nr. 1,

300222 Timisoara, Romania

E-mail: stocksproiect@yahoo.com

Dorin Lelea, PhD Professor

University Politehnica Timisoara,

Faculty of Mechanical Engineering

B-dul Mihai Viteazu nr. 1,

300222 Timisoara, Romania

E-mail: dorin.lelea@upt.ro 